\title{
EXHIBITION SPACE OF REMEMBRANCE: Rhythmanalysis of Memorial park Kragujevački oktobar
}

\author{
A B $S$ S T $T$ R A $A$ C $T$
}

War memorial architecture that emerged after World War II was a significant part of the building program of Yugoslavia. Marking the war events (traumas) is an important constituent of memory, and thus participates in the construction of contemporary knowledge regarding a given historical period. The aim of this paper is to present the influence of legislation and politics on the formation of the image of society and history of that period, through the analysis of the case study of Memorial park Kragujevački Oktobar in Šumarice, Kragujevac. After WWII, the dominant tendency in Yugoslav planning of memorials was to establish a new form of memorial park. Even though the building requirements in this case were clear, they were not carried out consistently, which left to the memorial incomplete. Nevertheless, within the Memorial park and Memorial museum in the park, there are several pieces of art of the highest quality, completed through a synthesis of different art disciplines. The influence of decisions of the authorities on the development of the Memorial park and the creation of its art will be described through the methodology of rhythmanalysis. The same analysis will be applied to determine how the construction of the park impacted the local community. 


\section{INTRODUCTION}

Memorial monuments were noticeably large group of registered monumental heritage in socialist Yugoslavia. According to the census that was created in 1986, there were more than 1500 monuments related to the World War II. ${ }^{1}$ During the next three years official revision with the strict criteria was done and the number of registered monuments was drastically reduced. ${ }^{2}$ However, this result has clearly demonstrated extensive distribution of monuments throughout the country. Describing the memorial monuments, Branislav $\mathrm{Krstic}^{3}$ has presented three subjects that were characteristic for the post-war memorial architecture of Yugoslavia: 1) struggle against the occupiers and tribute to the fallen soldiers; 2) recollection of the fascistic executions and crimes of genocide; 3 ) keeping the memory of the time of political (historical) transformation of the state. As observed, first and second subject are dealing with the recollection of important figures, places or events from the war (whether successful resistance or war suffering), that is, with the war narrative itself, while third subject requires a wider historical context that distinguishes polity before and after the war. This raises the question of how the theme of the historical transformation was included in the narratives of the first two subjects and how it could have been expressed independently. Considering that the Communist Party of Yugoslavia came to power with "victory over fascism" in the World War $\mathrm{II}^{4}$, it was of crucial importance how the narrative of the war events will be interpreted. In this context, the memorial park can be observed as an exhibition space of the state representation, where the question of choice of symbols and adopted language of art and architecture is posed.

After socialist period and division of Yugoslavia into independent states, many of these territories of remembrance have remained unfinished, repressed or their purpose was marginalized. ${ }^{5}$ One of the largest memorial parks in the Republic of Serbia ${ }^{6}$ is Memorial Park Kragujevački Oktobar in Šumarice, Kragujevac, which did not achieve its full potential (from design to construction) and it remained on the margins - both in the work of its authors and in the register of memorial architecture in Serbia.

The aim of this paper is to present interactions and relations of three mentioned factors: political transformation after the World War II; the memorial park as exhibition space of the representation of the new society; and thesis about marginalization of the memorial architecture that will be shown through changes in the everyday life of the community. In order to compare courses of the government decisions in the public space with art works that are represented, and in order to perceive changes in life of the local community, the adequate methodology was found in the rhythmanalysis ${ }^{7}$ of Henri Lefebvre. 
Through means of rhythmanalysis will be examined how rhythms shape the human experience in the space-time, and how they pervade everyday life. In this work dynamics of decision-making in the public space of Šumarice will be analyzed along with reference on rhythmic relation between planned and realized activities in the spatial development of Memorial park. Also, relations of memorial park with its environment will be explored, that is, rhythms of museums will be compared with rhythms of the park and of the city. The goal is to to clarify changes of meaning, as well as changes of functions of the Memorial park in time, by complex comparison of rhythms.

\section{NEW FORM OF MEMORIAL PARK}

Relation between the rhythm of decision-making and the rhythm of their realization directly affects everyday life of the community. Rhythmic recurrence of relation decision-realization rarely is a process isolated from external influences. It will be considered in what way social and political activities interrupt or change (accelerate or decelerate) these rhythms and it will be analyzed in what way polyrhythmia, arrhythmia and eurhthmia emerge in the process of decision-making and space planning.

The initial impulse in Šumarice was a tragic event that occurred on the $20^{\text {th }}$ and $21^{\text {st }}$ of October of the year 1941. More than 2300 inhabitants of Kragujevac were shot and buried in thirty mass graves on this territory. ${ }^{8}$ War trauma has initiated two impulses - one is time-related, determined by date; the other is spatial, determined by position of graves. First impulse started the rhythm of annual commemorative manifestations, while second was the basis for scope of Memorial park whose territory was determined according to the disposition of thirty mass graves.

Final meeting on the establishment of Memorial Park was held on the August 9, 1953 in Belgrade, eight years after the war. The first question of the debate were dimensions of the park (was the territory designated for that function too large), that question was followed by the one on property relations. Shortly was replied that "there is no problem regarding the issue of property relations." As for the explanation of size, two parameters were specified - one was related to inclusion of all mass graves, and the other was related to the existing General Urban Plan of Kragujevac, where the purpose of this area already was "park of forest type". 
In the discussion economic profitability was emphasized on several occasions as were necessary supporting contents that will animate park visitors (as indicated: spectacles) and the conclusion was that it is necessary to find a new form of liberation monument. The final idea was to have entire terrain arranged architecturally and artistically in one holistic garden-like urbanism. Beside the importance to mark revolutionary struggle, it was also emphasized that "if park connects with youth and their life, and if ... it gains economic justification, then the realization will be seen as successful." ${ }^{\prime \prime}$

The crucial question of the meeting was whether the park should be conceptualized as "monuments in the park" or as "park as a monument", that is, to what extent is it necessary to emphasize the monumental atmosphere in the park. One opinion was "not to highlight the graves ... but to emphasize recreational areas." ${ }^{11}$ However, the majority thought that "the graves ... should be primary and that everything else is of secondary importance and that the urban design should guide the visitor through the site." 12 The Final Report of the Committee concluded that "the starting point for designers should not be one holistic architectural or sculptural monument, but that the entire area should be designed as a memorial park that will present the big tragedy that took place in Kragujevac in 1941."13

Comparison of the concepts of memorial parks in different countries shows that they are programmatically and visually very different, in accordance with the political division of the World (Western and Eastern Bloc). Generally speaking, the Soviet memorials were part of the monumental expression of the socialist realism ${ }^{14}$, while in the examples from Western Europe was primarily investigated the possibility to completely devoid modern work of art of ideological connotation, setting in that way the counterbalance to the earlier political and propagandistic function of the Nazi and Stalinist production of monuments (before the War). ${ }^{15}$

After the exclusion of Yugoslavia form the Cominform in 1948, the state was turning away from Soviet socialist statism and making conciliatory efforts towards the United States. However, Yugoslavia entered neither the Warsaw Pact nor NATO, and it started to build its own conception of socialism, known as the Yugoslav path to socialism or the Third Way. Implementation of this model in the sociological sense started in 1952-53 when the idea was directed toward the necessity of giving more autonomy to companies, decentralization of the management in economy, as well as the revisionist idea of a market economy in 
socialism. These ideas were supposed to provide independent management of the working organizations in accordance with the laws of economy. ${ }^{16}$

While the overall government tendency was to implement a new form of self-governing socialism, in the competition program for Memorial park in Šmarice the main demand was to find a "new form of liberation monument."17 The announcement of the competition stated that:

This memorial park should not be a cemetery, even a modern one, nor should it be a monument for victims or to misdeeds of fascism, but primarily it should be a monument to the heroism and revolutionary of the working class...

this memorial park should be unique among its kind.

As such, it will give strength and inspire.

Competition results were announced in mid 1954, with no detailed description of the selection process. The winning proposal was from architects Mihajlo Mitrović, Radivoje Tomić and landscape architect Smiljan Klaić, and it was decided that the final project should be made in collaboration with two runner up teams from Rijeka and Zagreb. The famous Serbian architect Nikola Dobrović was invited to be the chief consultant on the project.

The preliminary design of the memorial park was finished in March 1955. The main feature of the park was the monumental promenade composed as a linear disposition of three elements: memorial museum - mausoleum - monument to victims. These buildings were located near the main entrance from the city to the park and were positioned on the gathering plateau for public events. The study for the preliminary design contained line of sight analysis, as well as a detailed plan of greenery developed and planned in phases, from the arboretum to the crop fields and vineyards in the later stages. The core of the concept was landscape architecture, as was said in the explanation of the design "the park is designed as a landscape where all buildings will be blended in the surroundings without overemphasized monumentality." 18

The first phase of the field works, which included construction of roads, pedestrian routes and water regulation, began already in 1955. ${ }^{19}$ A Youth Work Action was organized and "youth work brigades from Kragujevac volunteered." ${ }^{20}$ The preliminary design plan foresaw a sculpture on each mass grave and also, that each of the six Yugoslav republics should arrange a part of 
the memorial park. ${ }^{21}$ As we can see, all the elements of ideology were included in the symbolic narrative of the memorial park: Brotherhood and Unity (a popular slogan of the communist party), working class (through the concept of udarnik - strike worker) and revolution. We can draw a parallel between Youth Work Actions and Lefebvres notion that Marxists were interested in rhythms only through the concept of work, since collective work is in the first place organized rhythmically (for example, in field workers, sailors, shepherds etc. through collective singing). ${ }^{22}$

An article in a daily from 1955 states that the park will acquire its general shape by 1960, and be finished through phases in the following ten years. However, eleven years after the article appeared, in 1966, the General Area Plan was formulated and included an appraisal and revision of the park. In the period of eleven years not much had been done: construction of the roads had only been started, three grave monuments were erected and architects were chosen to work on the design for the Museum building.

The explanation offered in the General Area Plan was that "actual experience and material problems caused changes in the preliminary design." ${ }^{23}$ Although, as mentioned, the first meeting claimed that there were no legal and ownership problems, the new plan said that it was necessary to revise the borders of the area and reduce its size, in order to "enable easier takeover of the land from various owners." ${ }^{24}$ There was also a drastic change in the development of planned activities. An artificial lake was constructed on the river, independently of the initial plan. Since there was one mass grave in that area, it had to be displaced. Soon after, the lake became the new urban center where restaurants, coffee shops and sports facilities appeared..$^{25}$ The new General Area Plan diverted from previously planned activities and departed from the functions of memorial center.

At the same time when the General Area Plan was made, The Fund for Construction, Maintenance and Arrangement of the Memorial Park was established. This Fund merged its resources with a big company and factory Zavodi Crvena Zastava, based in Kragujevac. It was agreed that workers contribute with two working days a year from 1966 until 1970 (by when the park was planned to be finished). ${ }^{26}$ Workers should choose two of their non-working days in the year (usually a Sunday) and paychecks for those days would be put into the Fund. Hiring workers outside their working hours changes the social activities and as a consequence leads to the arrhythmia of leisure. 
One of the few buildings that were built by the first Plan from 1955 was the Memorial museum building. The two architects Ivan Antić and Ivanka Raspopović were a renowned team and they were contracted in 1964 and given a year to make the preliminary design. Indeed, the first drawings and model of the building were presented in the journal Architecture Urbanism in 1965. Starting with that year until the museum opening, we can notice certain changes between three design projects: the preliminary design in the journal from 1965, general project that was finished in 1967 and as-built state. The conception of the building remained the same through all phases, but there are some differences in the functional scheme and details of the building. Although the project of the museum was finalized and additional resources were obtained through the Fund, the contract with the construction company was signed only in 1971. Building was finished in four years and the opening ceremony was held on 21 October 1976.

The first law for the protection of monuments in Yugoslavia was the Law for the Protection of Cultural Property, passed in 1977. Only two years later, the Memorial park in Šumarice was declared a Cultural Monument of Exceptional Importance ${ }^{27}$, in the category of Historic Landmarks. This was the last decisive moment in the creation of the Memorial park. In the following years, the rhythm of the construction work slowed down. Most obvious is the example of monuments on the mass graves - each of the thirty graves was to get a monument, but only ten were erected, of which half before 1979 .

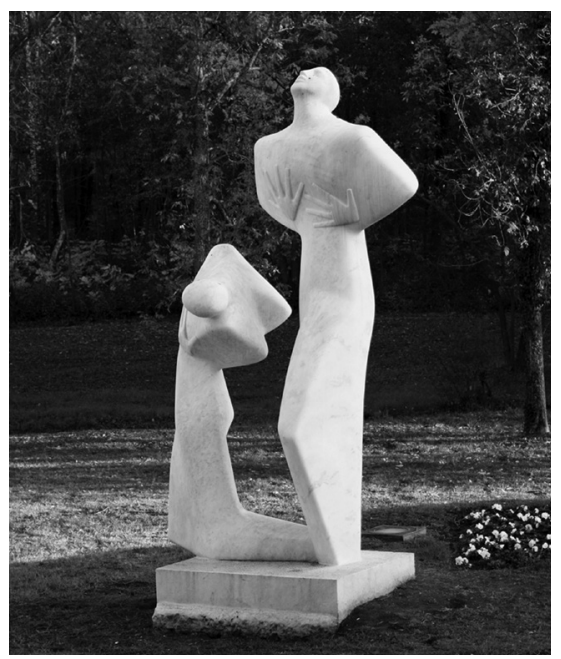

Figure 01. Photo by: Marko Jovanov 


\section{MEMORIAL MONUMENTS}

In the preface of the book Revolutionary Statuary, which shows broad overview of the most famous World War II monuments, art historian Juraj Baldani describes the development of sculpture concerned with social motives in Yugoslavia, starting from the late $19^{\text {th }}$ century. He describes the beginning of the $20^{\text {th }}$ century when social themes were expressed through formal display of the working class "but without class engagement." ${ }^{28}$ Before World War I, several artistic groups emerged, the members of which formed the after war art scene, advocating socialist realism. However, the new modern art concepts did not have a breakthrough in our country before the 1960s, when they were finally expressed through public and monumental sculpture. ${ }^{29}$ Baldani continues to present changes in the expression through simplification of the form, purification of details and reduction to sign, all of which were labeled as experimental avant-gardism and freedom of expression. As explained by Aleksandar Ignjatović in the text "Transition and reforms: architecture in Serbia 1952-1980"30, ideals such as freedom of creation and autonomy of arts were banded with the new view of society and culture and were proclaimed in the official political discourse as manifestation of free, self-governing society that moves toward a "new condition". As for the autonomy of arts, there is a question about closure in borders of the discipline, where an artist can be free to experiment and express his opinions, but at the same time legitimating the value system of the state, which represents itself as reformist and progressive. ${ }^{31}$ To what extent the experiments were closed within the discipline, we can see through Baldani's comments that "visual language ... constructs its own dramatic expression inside the theme", or that there is a tendency toward "constitution of monumental values contained within the plastic itself" where one can find "an autonomous organism ... which emerged out of the pure idea that was transposed to appropriate forms." ${ }^{32}$

The first monument erected in the Memorial park Kragujevački oktobar was Monument of Pain and Defiance (Figure 1) by sculptor Ante Gržetić, and it was officially unveiled on 21 October 1959. The monument is made of white marble and represents two human figures that Baldani describes as organic. Using a modern approach that tended to simplify shapes and make them sign-like ${ }^{33}$ opened the possibility to easily transfer characteristics of the shape from one to another medium. Graphic representation of the Monument of Pain and Defiance remained striking even when it was printed in DDR on the small format of postage stamps, titled "Monument in Kragujevac / SFR Yugoslavia" in 1967. 
Reducing the form to the sign gives the possibility for a sign to become a symbol. In that fashion, Monument to Executed Pupils and Teachers (Figure 2) by sculptor Miodrag Živković, become the symbol of the whole Memorial park. ${ }^{34}$ This monument was unveiled in 1963 and according to Baldani it represents that borderline where "figural becomes abstract" (Figure 3). By analyzing the reproduction of society and culture into art forms, Ignjatović is saying that in order to overcome mere utilitarianism it was necessary to construct an aestheticized world that would represent the projection of the ultimate goal of the movement of society as a whole. ${ }^{35}$ Therefore, the process of transition within sculpture can be represented as a shift from realism toward abstraction. Monument to Executed Pupils and Teachers is a good example of this transition, since it clearly strives to abstract expression but still contains real-image information. ${ }^{36}$

One of the most successful carriers of the abstract expression among sculptors in socialist Yugoslavia was Vojin Bakić who also has a sculpture in the Memorial park Kragujevački Oktobar. Jerko Denegri explains that it is enough to look at the titles of the series of Bakić's experiments such as Leaf Forms or Lightbearing Forms to understand that the artist made a mental leap into something that can be named completely abstract or non-referential sculpture. ${ }^{37}$ As Bakić explains his research of light forms:

I no longer see any possibility to express anything through figure. For example, when I was designing the monument for the memorial site Dotrščina ${ }^{38}$, I have found that the crystal, made out of reflective material, actually represents for us the same thing as the victims that were executed there: purity and permanent, eternal light. ${ }^{39}$

According to Baldani, Bakić represented hallmarks of the revolution through substantial visual characteristics and an atmosphere that came out of the core of the sculpture. This explanation can be contextualized through the European idea of the modern sculpture in the mid $20^{\text {th }}$ century that tended to answer the universal question: how to create a monument that would bear the expression of collective respect and at the same time to avoid any ideological discourse, in other words, how to find a universal sign that would escape the connotations of the human figure..$^{40}$

Bakić's sculpture Memorial From the People of Croatia (Figure 4) is located in the northeast part of Memorial park, on the hill facing the Memorial museum $21^{\text {st }}$ October. The monument was erected in 1981 and belongs to Bakić's series of experiments named Lightbearing Forms. The explanation in the competition 


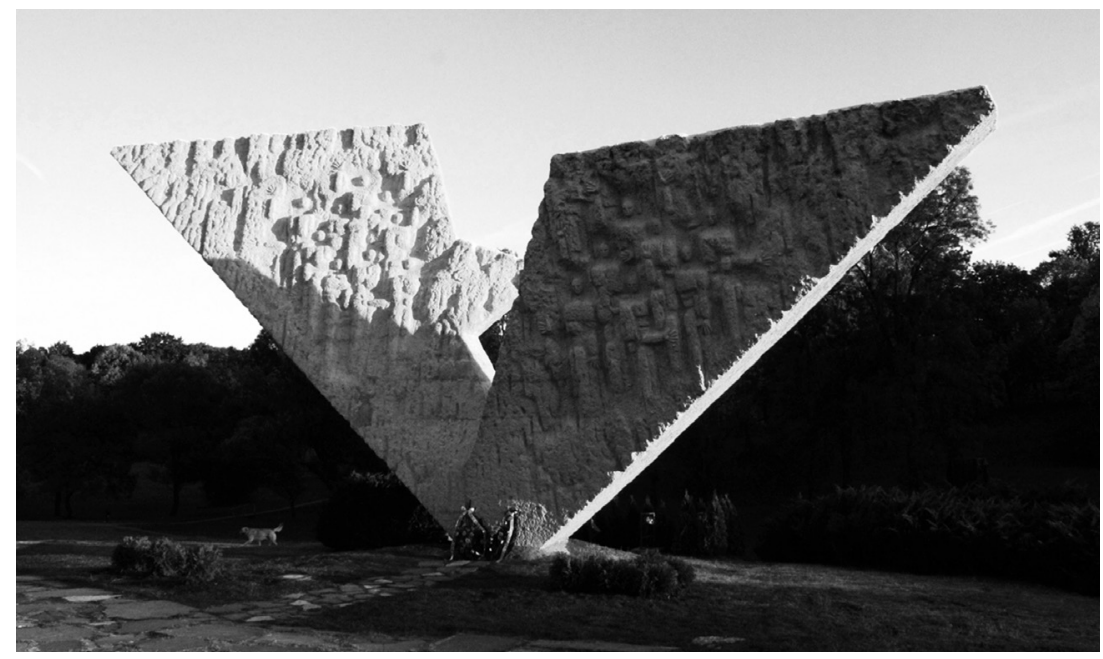

Figure 02. Photo by: Marko Jovanov

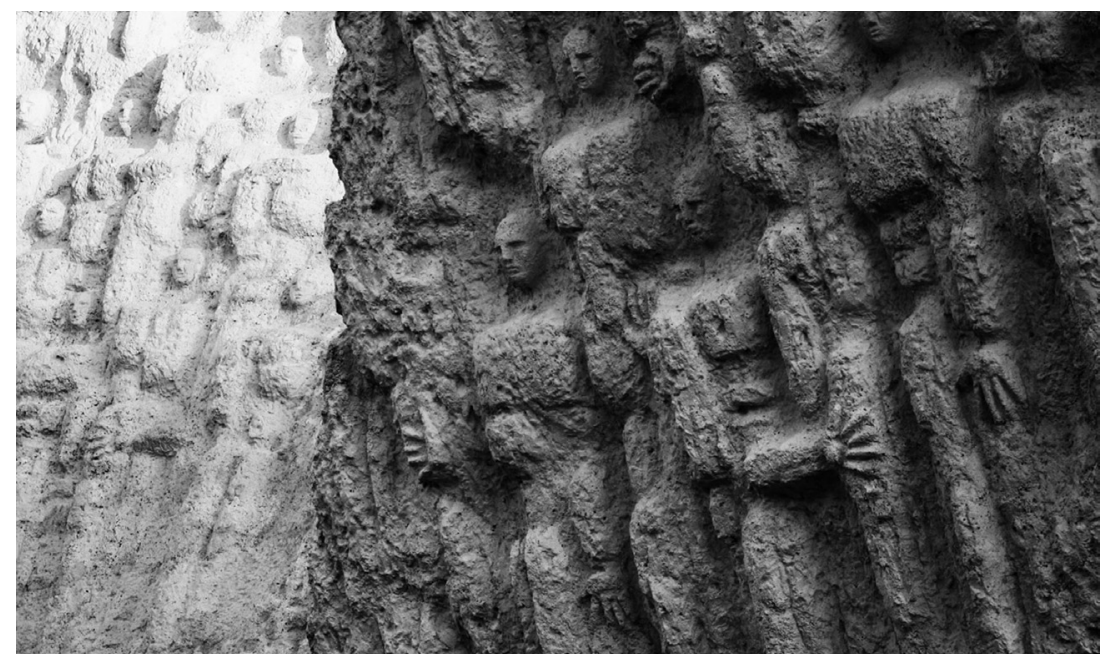

Figure 03. Photo by: Marko Jovanov

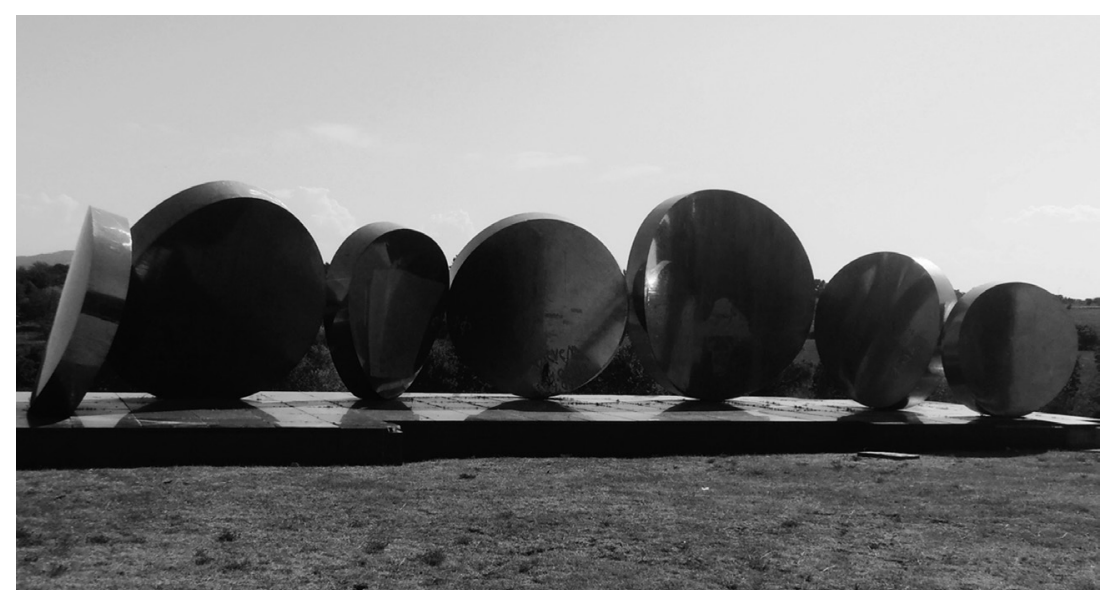


study for this monument was written by art-historian Vera Horvat-Pintarić who described the monument as seven circular convex plates made of stainless steel that are connected in polygonal bend. Circles are highly polished and due to different positions make specific light effects. The symbol of eternity is expressed through the form of a circle. Fragments of surrounding nature are reflected in mirror surfaces and are different depending of the viewpoint of the observer. Lefebvre's cyclic rhythms can be seen here through changes in the monument that reflect changes in weather and seasons. According to Vera Horvat-Pintarić: "the circular mirror arc binds together durability and permanence with the current, transient, variable." In the context of rythmanalysis, that is the example of interweaving of cyclical and linear rhythms. ${ }^{41}$

An area of 5 hectares, where Memorial From the People of Croatia is set, belongs to the Republic of Croatia and contains three mass graves (Figure 5). The horticultural project was done by Silvana Seissel and Josip Seissel, the team that already worked with Bakić on two memorial sites - Dotrščina near Zagreb and Kamenska. It was common practice for different professionals to work together on memorial sites: in addition to sculptors, there were $\operatorname{architects}^{42}$, poets, construction workers, landscape architects, etc. On one occasion, for the Monument of the Revolutionary Victory of the People of Slavonia by Vojin Bakić, it was necessary to test the structure since it was tall (30 meters) and in the form of leaves. The military industry from Belgrade was hired to examine parts of structure in special tunnels that test aircraft wings in gusts of wind and other weather conditions.

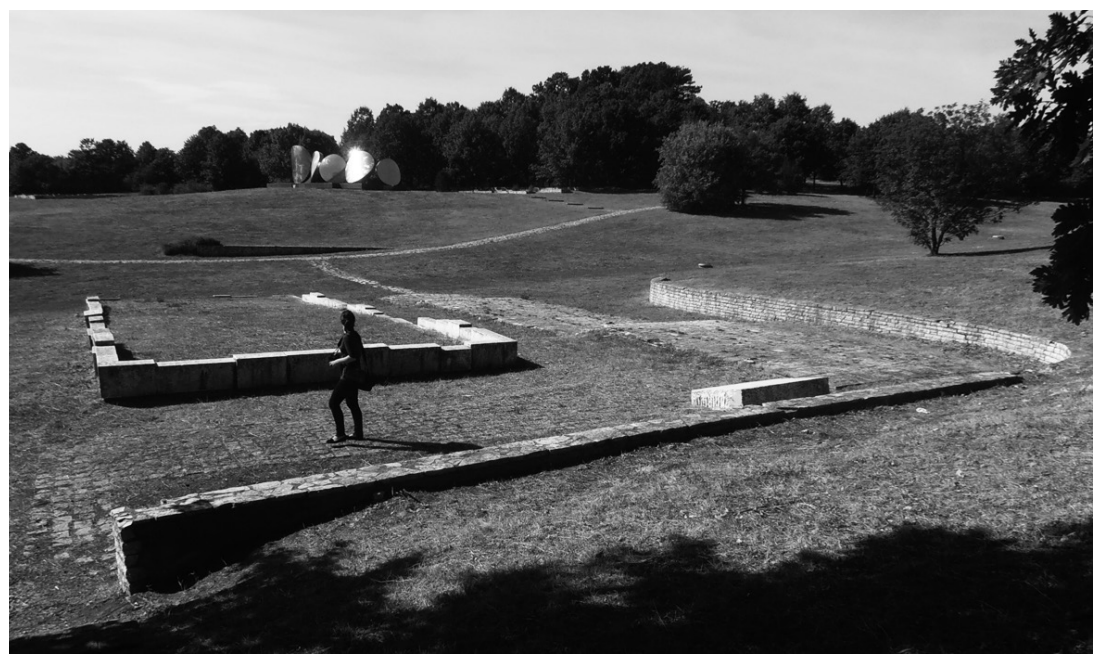

Figure 05. Photo by: Marija Martinović 
As Ignjatović writes, the idea of synthesis is established in a social context through the humanization and anesthetization of space that lead towards "optimal projection" of the new self-governed society. ${ }^{43}$ The synthesis in arts coincided with the change of social order that gravitated toward democratization $^{44}$, and it was especially present in the design and construction of memorial parks that were in constant search for a form that would embody "metaphorical presentation of a synthesized idea and reduction of geometry of symbol." ${ }^{\prime 45}$ The aim was to combine different art expressions that emerged from a tragic historical event or revolution and also to present those art works in space that can be used for official manifestations and commemorations. Verses or poems are often part of memorial monuments. Near the mass grave and the Monument to Executed Pupils and Teachers is an engraved plate with the most famous poem about the executed pupils in Šumarice, "A Bloody Fairytale", by poet Desanka Maksimović. As part of the landscape design of Memorial From the People of Croatia there are several plates (one at the entering point and three by the mass graves) with excerpts from "Open Poem" by the renowned Croatian poet, Jure Kaštelan. The poem was written for the central commemorative manifestation Great School Class in 1976. ${ }^{46}$

A circular path through the landscape site Memorial From the People of Croatia takes visitors around Bakić's monument and directs the walking line towards the graves. North of the monument, the natural slope is used to form an amphitheater surrounded by a wood and facing the monument. This space is suitable for gatherings, events and commemorations. Josip Seissel, one of the authors, explains that idea was to preserve and accent the form of the natural landscape. The grass hill is maintained with the addition of trees on the edges, in order to insulate it both aurally and visually. The goal was for this area to remain quiet and peaceful, allowing the visitor to contemplate and think. Colors and shapes are soft and natural, and the only visual embellishments planned were red rose bushes (which do not exist today). Seissel explained the aspiration toward synthesis in an interview from 1980 where he gave an example of memorial sites as the topic that requires synthesis by itself and the suffusion of different elements into an integrated whole. ${ }^{47}$

\section{MEMORIAL MUSEUM $21^{\text {st }}$ OCTOBER}

Šmarice is located uphill from the city center, making the Memorial museum $21^{\text {st }}$ October visible from a lot of places in Kragujevac. After World War II, the circle with thirty mass graves outlined the area of about 360 hectares that would soon become the Memorial park. Due to the growth of urban territory around the park, its position shifted from the city outskirts to becoming an inner city park. 
Figure (6) shows the scheme made by architect Veroljub Trifunović illustrating the growth of the city, position of the park and their interrelations. It explains how city activities became more and more present in the park as the city network interferes with that of the park (streets, bicycle paths, pedestrian zones, etc.). Connections for different parts of the city became integral part of the park over time.

A long, wide two-way street connects the city center with the memorial museum positioned at the park entrance in a straight line. Since the museum is uphill, there is a feeling of ceremonial approach to the building. This access road approaches the Museum from the back side; therefore, it is necessary to go around the building in order to find an entrance. The walk around the museum building changes the initial perception of the building form. The structure is revealed to the visitor as composed of a bundle of vertical cuboids of different heights. The rhythm changes with the movement of the observer - those vertical cuboids enter a dynamic relation of overlapping, growth, decline, etc. Architect Ivan Antić explains this relation: "a tight system of vertical cuboids is formed (similar to an organ) at the highest point of memorial park in order to dominate both the park and the city boulevard." ${ }^{98}$ (Figure 7)

Museum $21^{\text {st }}$ October expresses a clear intention to make a form that is entirely geometrical. In the words of its creator: "The only thing I ever wanted to make is pure geometrical form. Rational form. It should be square, triangle, circle, ellipse. You can see that through my work." ${ }^{\prime 49}$ For the museum building the spatial greed is formed as a cube, the side length of which is 3.12 meters. Basic modules are vertically stacked forming the bundle of vertical cuboids. There is a similarity of concept with another museum designed by the same team, the Museum of Contemporary Art in Belgrade. Ljiljana Blagojević describes both museums through the model of "continuous growth" ${ }^{50}$. However, it seems that in the case of Memorial museum the metabolist idea of development of structure by addition of standardized elements can be seen in the design process, since the building is composed as completed sculptural form. This is in contrast to the Museum of Contemporary Art where there actually was an idea of a honeycomb structure to which additions could be made. ${ }^{51}$

One more important characteristic of the Museum design is the connection between building and terrain. Vertical cuboids are descending from the middle toward the ends of the structure. At the opening ceremony, architect Antic said that he wanted to make the impression of a structure that grows from the terrain and, similar to a tree, pulls some soil with it. ${ }^{52}$ That is why the museum building 


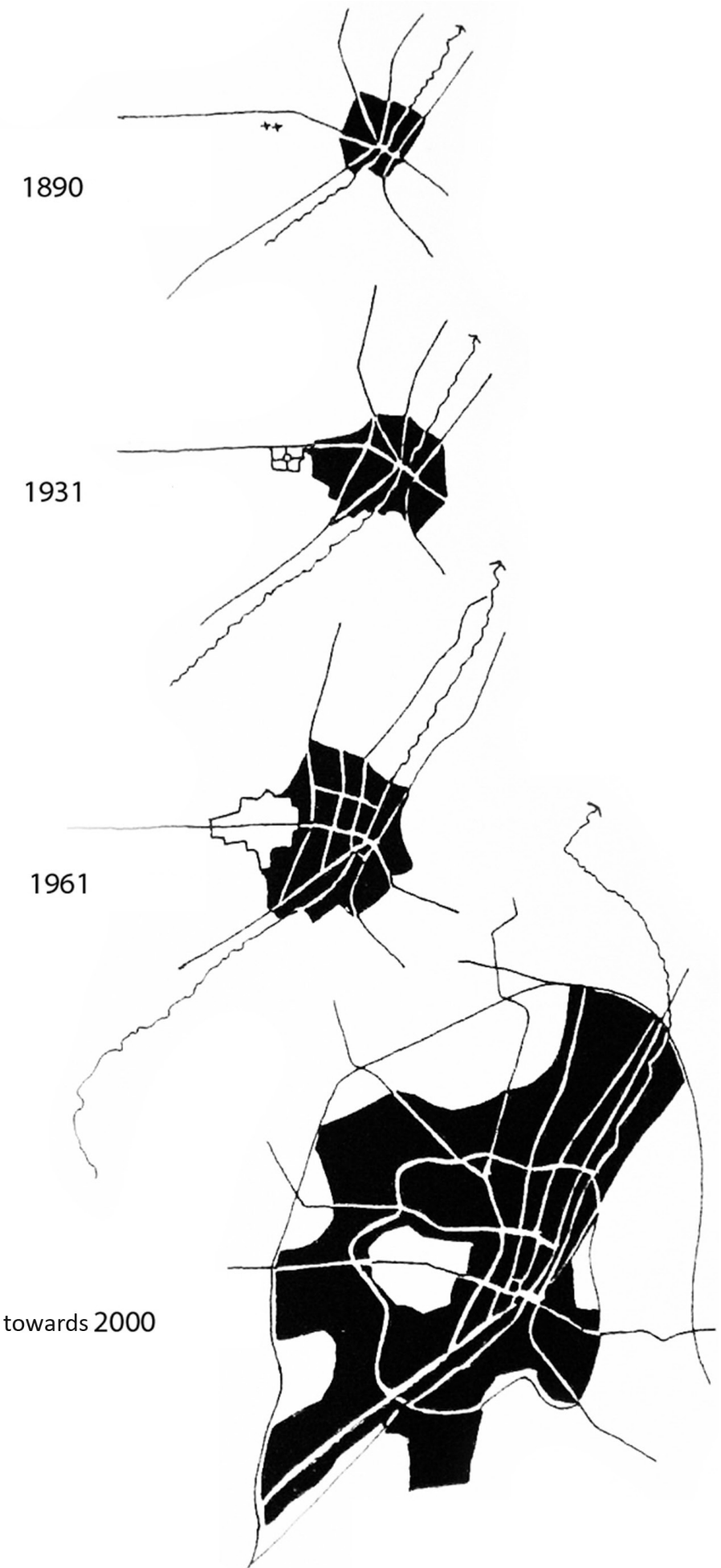


is placed on an artificial scarp. The idea was to connect building and nature, to blur the boundary between the artificial and natural - "the slope smoothed that sharp line between geometry and its natural surroundings." ${ }^{33}$

The rhythm of architectural space directs the visitor and adjusts his bodily rhythms. One of the examples given in Lefebvre's analysis of Mediterranean cities is that of stairs. Stairs also have an important role in the Memorial museum. There are three spiral staircases that enable a continuous walk through exhibits. The main entrance is one story lower than the outside plateau, so the first spiral staircase is placed in front of the building (Figure 8). Just after the glass doors at the main entrance, there is a brick wall. The visitor is forced to stop, to interrupt his walking rhythm. On the wall is an excerpt from a poem by Branko Miljković. ${ }^{54}$ Thus poetry becomes an integral part of the architecture and it is also a good example of interference of different rhythms: rhythm of the steps is suddenly interrupted because of the wall, in order for a new rhythm of poetry and words to arise. Behind the wall is a small hall which extends to an exhibition space for temporary exhibits on the lower level. In the same hall are the ticket office and an inconspicuous entrance to a projection room. This level also features a series of paintings by Petar Lubarda, Kragujevac 1941, part of the permanent exhibition. The painter was deeply inspired by the tragedy in Kragujevac and he donated a series of 27 paintings to the museum in 1969, with the written request that the paintings always be exhibited as a whole and never leave Kragujevac. At the end of the exhibition space there is another spiral staircase with a glass rooftop and green-planted walls which altogether makes a specific outside atmosphere that seems like a break from the exhibition space (Figure 9). On the upper floor, the dominant elements are tall brick cuboids that have the glass rooftops and resemble "wells that look into the sky." 55 Those cuboids are placed above the exhibition space on beams at different heights (Figure 10). The difference between the monumental, closed exterior and open-floor, light interior becomes evident. At the end of the permanent collection on the upper floor there is a third spiral staircase that goes down and connects the end of the exhibition with the entrance hall. Also, there is a separate exit that is placed right above the entrance (at the upper floor). All features that allow continuous flow of movement around the exhibition.

The museum space embodied the modern idea of open space, continuous walk around the exhibition and synthetic approach to design where different art forms (poetry, sculpture, painting and wall painting) are brought together. 


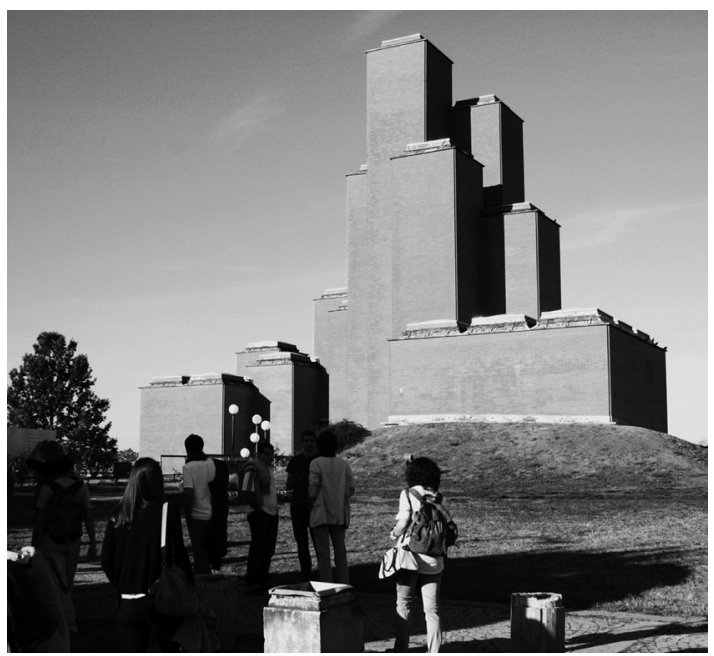

Figure 07 . Photo by: Marko Jovanov

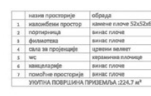

$\begin{array}{llllllllllll}11 & 21 & 31 & 41 & 51 & 61 & 71 & 81 & 91 & 101 & 111 & 121\end{array}$

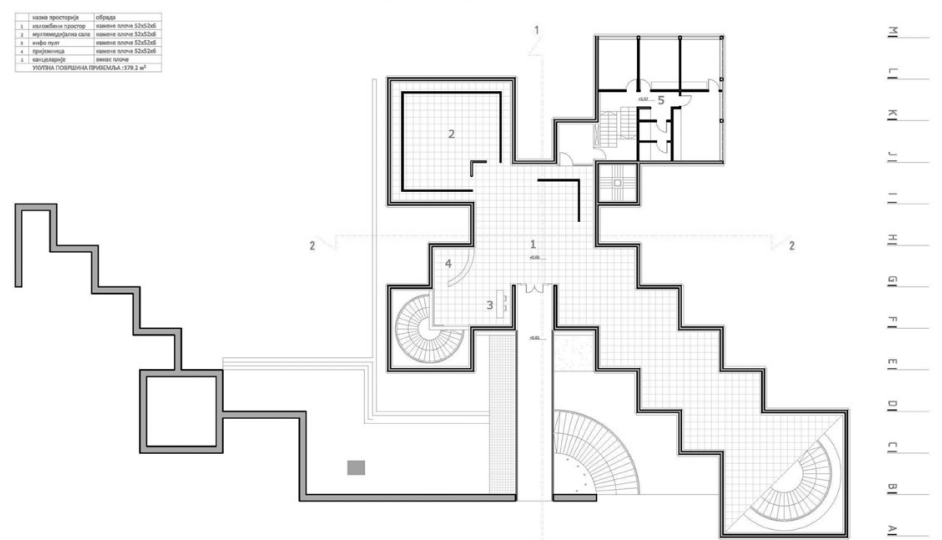



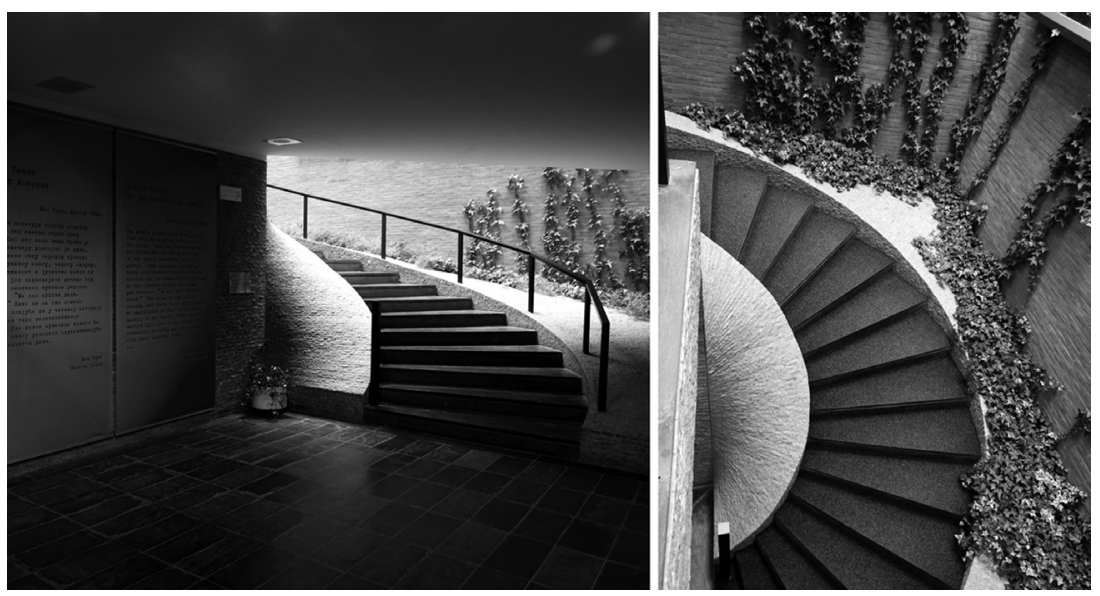

Figure 09. Photo by: Marija Martinović

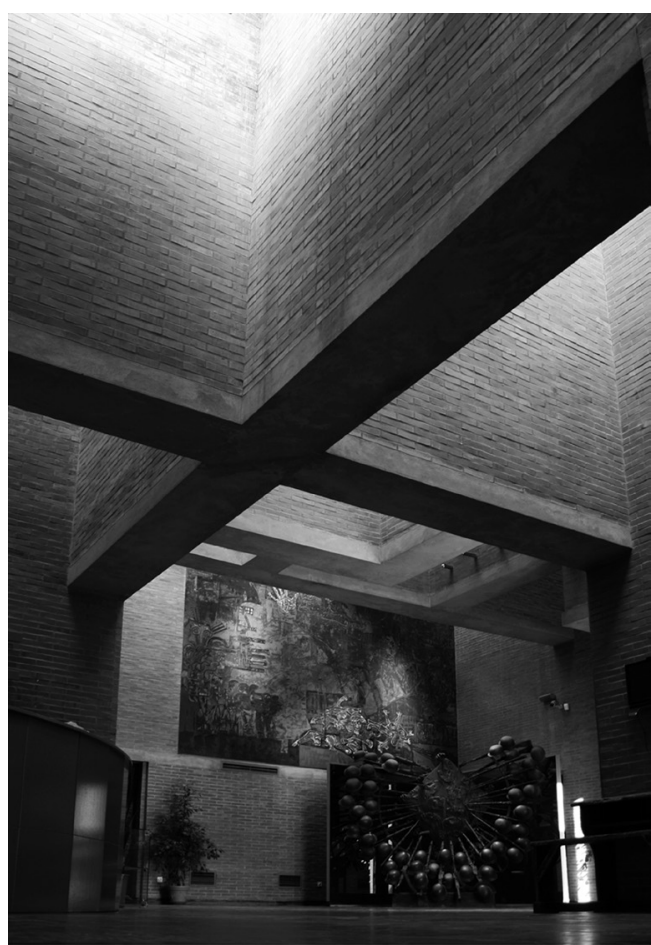

Figure 10. Photo by: Marko Jovanov 
The memorial museum in Šumarice, above all, represents a clear departure from the old form of memorial building ... it is neither a monument, nor utilitarian building, it is a work of strong expression, that brings ... complex experience, through full unity of the exterior, interior and content. ${ }^{56}$

\section{RHYTHMANALYSIS OF THE MEMORIAL PARK KRAGUJEVAČKI OKTOBAR}

What prevails in the soundscape ${ }^{57}$ of the park is the sound of wood and rustle of trees. The main road Kragujevac-Topola that runs through the park gives a continuous sound flow, independent of the rhythm of other activities in the park. Park activities mostly depend on weather. In the spring and autumn months, the park is crowded with different visitors - cyclists, runners, families on picnics and passers-by. In the summer months, the area around the lake becomes particularly active and noisy, since many inhabitants of the city come to swim and cool off by the lake. In the last couple of years a nightlife rhythm in the park has become more intense since there has been an increase in the number of night clubs. That is a new influence of city life that came unrestricted by any legal regulations.

The memorial museum represents a break from the soundscape of the park since its interior is isolated from outside noises and the only sound to be heard is the voice reading names of victims. Another rhythm that is specific for the museum is the rhythm of the exhibition changes. That is the linear rhythm which is a direct consequence of the rhythm of social changes. The permanent collections and temporary exhibits are pulsing at different paces. The new permanent exhibition that was set up in 2003 represents a big disruption since it signifies a break with the previous view of historical data as well as a criticism of the old permanent collection, seen as "esthetically far below the artistic level of architecture of the building, making the exhibition space confusing, vague and ultimately repulsive, which resulted in a reduced number of visitors. ${ }^{" 58}$ The rhythm of change on the permanent collection depends on a wider socio-political atmosphere, reflecting changes in attitude towards history. In contrast, temporary exhibits change frequently and are usually not in direct relation with the memorial. Here, the rhythm of change of temporary exhibitions is in correlation with art production in Kragujevac and depends on the cooperation of the museum with artists. 
Rhythm, as a base of everyday life, is a combination of cyclical and linear repetition, that together produce mechanical, rational and structural elements of social life, repose (leisure) and work, together with cosmic and organic cycles. ${ }^{59}$

At the core of every memorial space is a cyclical activity: commemoration. Performativity is a sensory and perceptual category which shapes the feeling of time in a public space. Every year the rhythm of events intensifies in the months before the commemoration on 21 October. The same thing happens with the rhythm of art production and publishing activities. Starting in 1971, there has been an annual central commemorative service named Great School Class in front of the Monument to Executed Pupils and Teachers. In this theatrical manifestation numerous plays and compositions have taken place over the years. Every year, one performance with a pacifist message is chosen, regardless whether its author is a national or foreign, and participants are usually famous actors, opera singers or choirs. There is also a traditional music ceremony called Oktobru hododarje - OKTOH, begun in 1975. For this occasion young musicians play famous musical pieces. Also, for more than thirty years there has been a competition for pupils of primary and secondary schools in literature and painting. Occasionally, there are initiatives that come outside of the memorial structure such was, for example, manifestation Architecture Class organized in 2012 by three young $\operatorname{architects}^{60}$ as a way of promoting memorial heritage. Aside from the standard presentation of memorial heritage (visit to the museum with a historian from the museum and guided tour around the memorial park) the program of this event also included a movie about the design process of the Memorial museum $21^{\text {st }}$ October, presentations by various experts and a roundtable discussion including experts and visitors. The particularity of the manifestation Architecture Class was

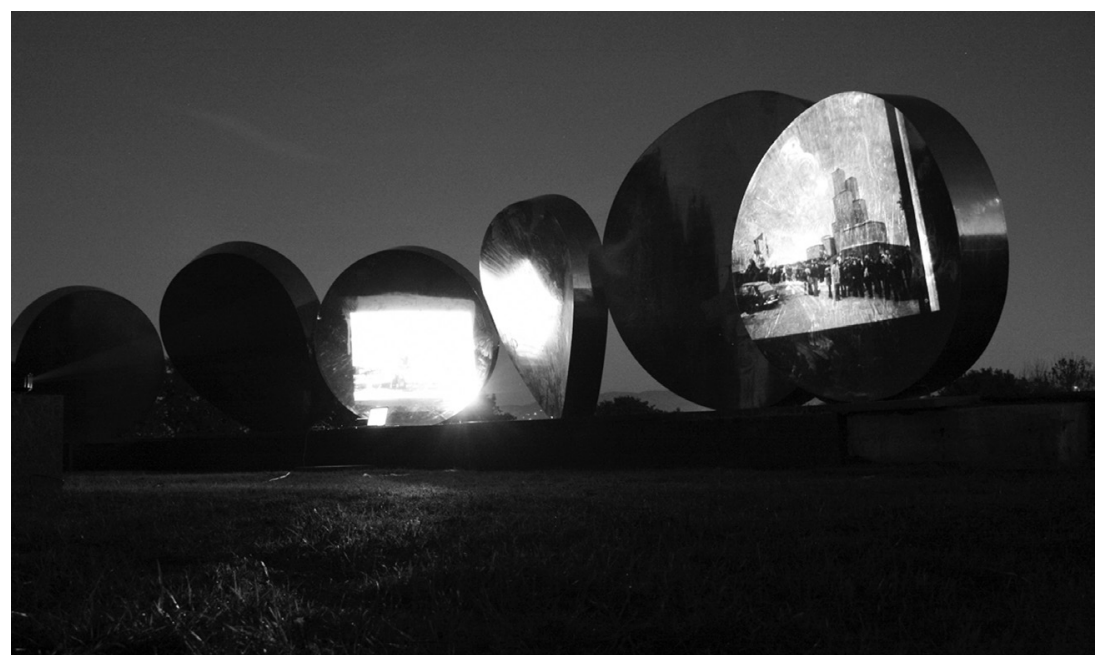

Figure 11. Photo by: Marko Jovanov 
the presentation of historical materials about the museum collected from the archives. A slide-show of photos, drawings and documents was presented at dusk on the reflective surface of the monument Memorial From the People of Croatia (Figure 11). The atmosphere in this area of the park enabled visitors to gather in the amphitheater next to the monument and relax while watching photos, documents and drawings about development of the park. Thus, the presentation Architecture Class served as an experiment in the development of new approaches to the use of memorial parks and a reassessment of the traditional relation toward archive materials.

Throughout all the abovementioned activities, people gathered and visited the museum and monuments, restoring the memory of victims. However, changes in the program, exhibitions and usage of architectural space, lead us to the question about the change of memory in time. That question includes considerations of the function of memorial objects (architecture and sculpture), their duration and adaptation to changes.

We can notice an ambivalent relationship between the ritual and rhythm. First, every ritual has its own time and its own system of gestures, narration and behavior. Second, according to Lefebvre, rituals penetrate into everyday life and punctuate it. Such events belong to non-quotidian rhythms and do not disturb everyday life. These are, for example, religious rituals, festivals and different ceremonies, including commemorations as well. ${ }^{61}$

The collective activity of manifestations affects the change of rhythm in space. Every group of people, gathered in a procession or parade, creates some kind of attractive or repellent force in the surrounding space. Collective activity imposes spatial relations, occupies certain amount of time and changes the perception of time through the determined order of rituals. Rhythmanalysis offers two types of experience: continuous experiences and experiential events $^{62}$. The first type includes unconscious repetitive everyday experiences; the second are those experiences that differ from continuity and stay in our memory. We tried to present and explore the interaction and intersection of those two types of experience on the example of Memorial park Kragujevački oktobar. The memorial park is becoming an integral part of the city's urban space and it has become ever more connected with the life of the city. Thus, both types of experience equaly represent everyday life of the community and constitute the space for different events. 

October in Šmarice written for the course Science of Space, as part of PhD studies at the Faculty of Architecture, University of Belgrade, Professor Dr Ljiljana Blagojević.

B. Krstić, Spomenička baština svjedočanstvo i budućnost prošlosti (Sarajevo, Zagreb: SYNOPSIS, 2010), 440-441.

According to the Census from the year 1986, 1531 memorial (grave) monuments were registered. Branislav Krstić explains the reasons for for the disproportionately large number of monuments declared as cultural monuments, as well as the way the revision was performed, after which was abandoned 1058 monuments. From this data follows that in the list of monuments remained 473 registered memorial monuments. B. Krstić, Spomenička baština svjedočanstvo i budućnost prošlosti (Sarajevo, Zagreb: SYNOPSIS, 2010), p. 440.

Branislav Krstić was the vice president of the Committee for Urbanism and Spatial Planning of the Federal Assembly (1965-1967), federal advisor in the Government of Yugoslavia responsible for urbanism, spatial planning, environment and heritage (1968-1982), president of the Federal Board for the architectural and natural heritage in the Government of Yugoslavia (1975-1982).

Look at: B. Horvat, An Essay on Yugoslav Society (New York: International Arts and Sciences Press, 1969).

Look at: Manojlović Pintar i Ignjatović, „Prostori selektivnih memorija: Staro sajmište u Beogradu i sećanje na Drugi svetski rat“, u: Kultura sjećanja: 1941. Povjesni lomovi i savladavanje prošlosti, ur: Cipek, T. et al. (Zagreb: Disput, 2008), 95-111.

Veroljub Trifunović compares surface of the Kragujevac Park with the Central Park in New York and Boulogne Forest, which have similar dimensions. Veroljub S. Trifunović, Urbanizam Kragujevca: dvadeseti vek. Knj. 1, Period od 1878. do 1974. godine (Kragujevac: Direkcija za urbanizam i izgradnju, 2004), str. 139.

By basing his philosophy on the questioning and criticism of Marxism, Henry Lefebvre elaborated study of rhythmanalysis as a response to the criticism of reification, assuming that the criticism of this process will be developed in the modern thought. Rhythmanalysis is defined as a method and as a theory "Analysis of rhythms in its full range' from particles to galaxies' has transdisciplinary character. Analysis gives itself a goal to, among other things, minimally separate scientific from poetic". Henri Lefebvre, Rhythmanalysis. Space, Time and Everyday Life, Stuart Elden, Gerald Moore trans. (New York: Continuum, 2004), 6.

"In order to complete anticipated number of 2300 ...today, regardless of personality, were arrested men between 16 and 60 years of age, on the streets, squares, workshops, apartments..." Taken from the exhibition of museum, Report of Captain Bischofshausen from the 20 October 1941, About the mass executions in Kragujevac. Today, it is estimated that 2795 citizens of Kragujevac have been executed. Brkić, Staniša. Ime i broj: Kragujevačka tragedija 1941. Kragujevac: Spomenpark Kragujevački oktobar, 2007.

Živković, M. "Minutes from meeting" typed text (8 pages), dated 9 August in 1953. in Belgrade, Archives of the Museum "21st October”, Kragujevac, folder: Material on the establishment of the Memorial Park, p. 1

Ibid, 2.

Ibid, 4.

Ibid.

Amended program report of the commission. "The conditions of the competition for the conceptual project Memorial Park October's victims", typed text (5 pages), dated 9 August 1953. in Belgrade, Archives of the Museum "21st October”, Kragujevac, folder: Material on the establishment of the memorial park.

Look at: Benjamin Forest and Juliet Johnson, "Unraveling the Threads of History: Soviet-Era Monuments and Post-Soviet National Identity in Moscow", Annals of the Association of American Geographers, vol. 92, no. 3 (Sep., 2002), pp. 524-547. 
Ljiljana Kolešnik, "Hrvatska spomenička skulptura u kontekstu europskog modernizma druge polovice 20. stoljeća: primer V. Bakića”, Novine Novine 12 (2007): 32-39.

Zagorka Golubović, Криза идентитета савременог Југословенског друштва: Југословенски пут у социјализам виђен из различитих углова (Београд: Филип Вишњић, 1988), 213.

Program report of the competition, in the folder: Material on the establishment of the Memorial Park 9 August 1953, unpaginated.

M. Mitrović, R. Tomić, S. Klaić. „Idejni projekat za Spomen-park u Kragujevcu“, Beograd, Mart 1955. str. 2.

There are two streams, Sušički and Erdoglijski.

R. J., „Nastavljaju se radovi na izgradnji Spomen-parka“, novinski isečak, iz arhiva Muzeja 21. oktobar, Kragujevac

Dušan Matić, Vojin Bakić: moj prijatelj (Zagreb: Euroknjiga, 2007), 138.

Those are the rhythms of the linear work that Lefebvre criticizes observing the crossing of rhythmic life processes and linear actions.

General Area Plan of the memorial park in Kragujevac. Beograd, 1966.

Ibid.

From: General Arrangement Plan of the memorial park in Kragujevac. Beograd, 1966.

Contract on pooling of resources for construction of the memorial museum of victims of fascism in Kragujevac, between the Fund for construction, maintenance and organization of the Memorial Park and Institute "Crvena zastava", Kragujevac, 1 November 1966.

In order to obtain status of "great importance", immovable cultural property should have some of the characteristics: "special significance for the social, historical and cultural development of people in the national history, that is, for development of its natural environment; testifies about crucial historical events and personalities and their activities in the national history; represent unique (rare) examples of creativity of his time and unique specimens of natural history; great impact to the development of the society, culture, technic and science; has an exceptional artistic or aesthetic value. "Taken from the Law on Cultural Property, Službeni glasnik RS, 71 / 94th Article 5 .

Jurij Baldani, Revolucionarno kiparstvo (Zagreb : Spektar, 1977), 9.

Ibid., 15.

Aleksandar Ignjatović, “Tranzicija i reforme: arhitektura u Srbiji 1952-1980”, u Istorija umetnosti u Srbiji XX vek. Realizmi i modernizmi oko Hladnog rata, ur. Miško Šuvaković et al. (Beograd: Orion Art i Katedra za muzikologiju Fakulteta muzičke umetnosti, 2012), 689-710.

Ibid., 692.

Jurij Baldani, Revolucionarno kiparstvo (Zagreb : Spektar, 1977), 15-16.

Jelena Davidović, "Tri spomenika u Spomen-parku 'Kragujevački oktobar”, Šumadijski anali 2 (2005): 239.

The sign is used as logo of the Memorial Park, and also in the visual identity of the museum. Ignjatović, "Tranzicija i reforme: arhitektura u Srbiji 1952-1980", 700.

Jurij Baldani, Revolucionarno kiparstvo (Zagreb : Spektar, 1977), 16.

Jerko Denegri, intervju, Novine Novine 12 (2007): str. 26.

Dotrščina is a memorial park in Zagreb, placing of Vojin Bakić's sculpture was in the year 1986. and project was developed in collaboration with Silvana Seissel and Josip Seissel.

Vojin Bakić, citat, Novine Novine 12 (2007): str. 6.

Ljiljana Kolešnik, "Hrvatska spomenička skulptura u kontekstu europskog modernizma druge polovice 20. stoljeća: primer V. Bakića”, Novine Novine 12 (2007): 32-39.

Josip Seissel, "Spomen-obilježje Hrvatske u Spomen-parku u Kragujevcu”, Bulletin (1981): 29-30. Some of the examples: Memorial Complex Kadinjača, near Užice, sculptor Miodrag Živković, architect Aleksandar Djokić, Monument to the fallen soldiers in Bilečište, sculptor Jordan Grabulovski, architect Venzcler Fedor, Memorial cemetery for fallen soldiers in Priština, sculptor and architect Svetislav Ličina and architect Pravoslav Janković, monument Makedonium, near Kruševo, sculptor Jordan Grabuloski and architect Iskra Grabuloska. 
Ignjatović, "Tranzicija i reforme: arhitektura u Srbiji 1952-1980", 705.

Ibid.

Baldani, Revolucionarno kiparstvo, 16.

Here are a few verses: "I say Kragujevac but I see Guernica, Dachau, Mathauzen, Oradur... I say Jasenovac, Buchenwald, Osvjencim but I see Kragujevac. Oh heart of the Šumadija, you beat in the man's heart . Liberty bell in the chest of the world.“

Josip Seissel, intervju, manuscript, Zagreb, 1980.

Antić, Technical report for the main project of the memorial museum in Kragujevac from 1967, project no. 3848/66 1971, p. 2.

Quote of Ivan Antić taken from the text: Dijana Milašinović Marić, „Disciplina arhitekture i sloboda duha, arhitekta Ivan Antić“, Arhitektura i urbanizam (Beograd), br.16-17 (2005), str. 7-13.

Ljiljana Blagojević, Novi Beograd: osporeni modernizam (Beograd: Zavod za udžbenike, Arhitektonski fakultet, Zavod za zaštitu spomenika kulture grada Beograda, 2007), str. 235.

Ignjatović, "Tranzicija i reforme: arhitektura u Srbiji 1952-1980", 703.

Antić, Technical report for the main project of the memorial museum in Kragujevac from 1967, project no. 3848/66 1971, p. 6 .

Ibid.

"And let it be the end and the beginning / of the world that will have their name and our hands / here where the history spoke out loud / here where they left their blood to shine / here where from their death lives earth, water and air."

Solution of the construction was done in collaboration with B.Sc engineer Tihomir Djokić. The construction of museum is armed concrete, and final processing is from the brick of roman format. Antić, Technical report for the main project of the memorial museum in Kragujevac from 1967, project no. 3848/66 1971, p. 4-5.

Zoran Manević, „Dostojan spomenik žrtvama i epopeji“, Večernje novosti (Beograd), 23. mart 1976, nepaginirano.

Soundscape is a technique from the 1960s when began the acustic explorations of the cities and more attention is paid to noise pollution, which is seen as a result of poor urban planning. In the appliance of the rhythmanalysis description of the soundscape the investigators are using often as auxiliary tool. Look at: Filipa Matos Wunderlich, „The Aesthetics of Place-temporality in Everyday Urban Space: The Case of Fitzroy Square“, y: Tim Edensor, Ed., Geographies of Rythm. Nature, Place, Mobilities and Bodies (e-Book: Ashgate, 2010), 51.

Igor Stepančić, „Estetika sadržaja istorijskih činjenica - umetnost prezentacije nasleđa“, web: http://www.scribd.com/doc/46581227/Igor-Stepancic-Estetika-Sadrzaja

Craig Meadows, “'I'm in a Park and I'm Practically Dead': Insomnia, Arrhythmia and Withnail and I", u: Tim Edensor, Ed., Geographies of Rythm. Nature, Place, Mobilities and Bodies (e-Book: Ashgate, 2010), 84.

Architects Tamara Popović, Jovan Grbović and Marija Martinović (text author), have initiated a project with support of the City Assembly of Kragujevac and informal architect organization - NOA Henri Lefebvre, Rhythmanalysis. Space, Time and Everyday Life, Stuart Elden, Gerald Moore trans. (New York: Continuum, 2004), 94.

Ben Highmore, "Routine, social aesthetics and the ambiguity of everyday life," Cultural Studies 18 (2/3) (2004): 315. 
Baldani, Jurij. Revolucionarno kiparstvo. Zagreb : Spektar, 1977.

Blagojević, Ljiljana. Novi Beograd: osporeni modernizam. Beograd: Zavod za udžbenike, Arhitektonski fakultet, Zavod za zaštitu spomenika kulture grada Beograda, 2007.

Brkić, Staniša. Ime i broj: Kragujevačka tragedija 1941. Kragujevac: Spomen-park Kragujevački oktobar, 2007.

Conlon, Deirdre. "Fascinatin' Rhythm(s): Polyrhythmia and the Syncopated Echoes of the Everyday". In Geographies of Rythm. Nature, Place, Mobilities and Bodies, Ed. Tim Edensor. E-book: Ashgate, 2010.

Davidović, Jelena. “Tri spomenika u Spomen-parku 'Kragujevački oktobar”. Šumadijski anali 2 (2005): 236-254.

Denegri, Jerko. Intervju. Novine Novine 12 (2007): 24-29.

Forest, Benjamin and Johnson, Juliet. "Unraveling the Threads of History: Soviet-Era Monuments and Post-Soviet National Identity in Moscow". Annals of the Association of American Geographers, vol. 92, no. 3 (Sep., 2002): 524-547.

Golubović, Zagorka. Криза идентитета савременог Југословенског друштва: Југословенски пут у сочијализам виђен из различитих углова. Београд: Филип Вишњић, 1988.

Highmore,Ben. "Routine, social aesthetics and the ambiguity of everyday life." Cultural Studies 18 (2/3) (2004): 312-320.

Horvat, B. An Essay on Yugoslav Society. New York: International Arts and Sciences Press, 1969. Ignjatović, A. i Manojlović-Pintar, O. „Prostori selektivnih memorija: Staro sajmište u Beogradu i sećanje na Drugi svetski rat“. U: Kultura sjećanja: 1941. Povjesni lomovi i savladavanje prošlosti, ur: Cipek, T. et al. Zagreb: Disput, 2008.

Ignjatović, Aleksandar. "Tranzicija i reforme: arhitektura u Srbiji 1952-1980”. U Istorija umetnosti u Srbiji XX vek. Realizmi i modernizmi oko Hladnog rata, ur. Miško Šuvaković et al. 689-710. Beograd: Orion Art i Katedra za muzikologiju Fakulteta muzičke umetnosti, 2012

Kolešnik, Ljiljana. "Hrvatska spomenička skulptura u kontekstu europskog modernizma druge polovice 20. stoljeća: primer V. Bakića”. Novine Novine 12 (2007): 32-39.

Krstić, Branislav. Spomenička baština svjedočanstvo i budućnost prošlosti. Sarajevo, Zagreb: SYNOPSIS, 2010.

Lefebvre, Henri. Kritika svakidašnjeg života. Zagreb: Naprijed, 1988.

Lefebvre, Henri. Rhythmanalysis. Space, Time and Everyday Life, Stuart Elden, Gerald Moore trans. New York: Continuum, 2004.

Matić, Dušan. Vojin Bakić: moj prijatelj. Zagreb: Euroknjiga, 2007.

Meadows, Craig. “'I'm in a Park and I'm Practically Dead': Insomnia, Arrhythmia and Withnail and I". In Geographies of Rythm. Nature, Place, Mobilities and Bodies, Ed. Tim Edensor. E-book: Ashgate, 2010.

Milašinović-Marić, Dijana. „Disciplina arhitekture i sloboda duha, arhitekta Ivan Antić“. Arhitektura i urbanizam (Beograd), br.16-17 (2005): 7-13.

Manević, Zoran. „Dostojan spomenik žrtvama i epopeji“. Večernje novosti (Beograd), 23. mart 1976, nepaginirano.

Seissel, Josip. "Spomen-obilježje Hrvatske u Spomen-parku u Kragujevcu”.Bulletin 1 (1981): 27-33. Stepančić, Igor. "Estetika sadržaja istorijskih činjenica - umetnost prezentacije nasleđa". Web: http://www.scribd.com/doc/46581227/Igor-Stepancic-Estetika-Sadrzaja.

Trifunović, Veroljub S. Urbanizam Kragujevca: dvadeseti vek. Knj. 1, Period od 1878. do 1974. godine. Kragujevac: Direkcija za urbanizam i izgradnju, 2004.

Wencler, Fedor. "Spomen područja kao specifična kategorija obilježavanja lokaliteta i memoriranja značajnih događaja iz narodnooslobodilačke borbe". Arhitektura (Zagreb), br. 155 (1975): 19-23.

Wunderlich, Filipa Matos. „The Aesthetics of Place-temporality in Everyday Urban Space: The Case of Fitzroy Square“. In Geographies of Rythm. Nature, Place, Mobilities and Bodies, Ed. Tim Edensor. E-book: Ashgate, 2010. 


\section{IZLOŽBENI PROSTOR SEĆANJA:}

\section{Ritamanaliza Spomen-parka Kragujevački oktobar}

\section{Marija Martinović}

Ratna memorijalna arhitektura u Jugoslaviji nakon Drugog svetskog rata čini značajan deo graditeljskog programa. Označavanje događaja (trauma) iz Drugog svetskog rata je važan činilac sećanja i izgradnje savremenog sistema znanja o tom istorijskom periodu. Cilj rada je da prikaže uticaj dominantne politike na formiranje slike o društvu i istoriji, kroz analizu slučaja Spomenparka Kragujevački oktobar u Šumaricama u Kragujevcu. Nakon Drugog svetskog rata težilo se ka novoj formi spomen-parka. Iako su zahtevi bili jasno koncipirani, odluke vlasti nisu bile dosledno sprovođene što je dovelo do nepotpunog ispunjavanja planova u izgradnji parka. Uprkos tome, u okviru spomen-parka i memorijalnog muzeja ostvarena su umetnička dostignuća visokog dometa, najčešće kroz sintezu različitih umetničkih disciplina. Metodom ritamanalize biće opisan uticaj odluka o razvoju spomen-parka na ostvarivanje $\mathrm{i}$ izbor umetničke produkcije, kao i uticaj na promene u svakodnevnom životu lokalne zajednice.

KLJUČNE REČI: MEMORIJALNI SPOMENIK, MEMORIJALNI MUZEJ, SINTEZA UMETNOSTI, RITAMANALIZA, SPOMEN-PARK KRAGUJEVAČKI OKTOBAR

Akademski kurs:

KUSTOSIRANJE: Tehnologija izložbenog procesa /

Realizacija projekta - "stvaran svet"

\section{Andrej Bereta, Srdjan Tunić}

Kao produžena aktivnost nezavisnog kustoskog projekta Kustosiranje / About and around curating, istoričari umetnosti i freelance kustosi Bereta i Tunić su razvili poseban akademski kurs za Univerzitet u Beogradu - Arhitektonski fakultet i Fakultet likovnih umetnosti tokom jesenjeg semestra 2012/13. god. Zasnovan na metodologiji iskustvenog učenja i inspirisan savremenim kustoskim studijama u Evropi, kurs je imao zvaničan kurikulum koji je u sebe okupio studente osnovnih studija arhitekture, primenjenih umetnosti (Odeljenje za vajarstvo) i istorije umetnosti. Cilj kursa je bio da podstaknemo timski rad studenata sa različitih studija da bi zajednički napravili nova umetnička dela, kao deo grupne izložbe. Sam kurs je bio oblikovan kao reakcija i konstruktivna kritika nedostatku saradnje između umetničkih fakulteta, malog broja praktičnih aktivnosti tokom studija i sagledavanju kustoskih studija kao čistog sveta ideja. 